\title{
England, Englishness and the Labour Party
}

\begin{abstract}
Recent research has indicated that English identity was a strong predictor for a Leave vote in the referendum on membership of the European Union, and that it is an identity that is increasingly playing a role in British politics. In this paper, we explore whether Englishness affects even left-right positioning of parties. Focusing on Labour, we find that it does, even controlling for other attitudinal and demographic variables. Perceptions of immigration change and perceived lack of political efficacy also play a significant role. Given the potential electoral significance of this, we reflect on and propose a range of policy options that Labour could utilise to address this gap between English-identifiers and the party.
\end{abstract}

Keywords: Englishness, Labour Party, left-right, British politics, left-behind, immigration.

\section{$\underline{\text { Author details }}$}

First Author

Professor Rt Hon John Denham

Professor of English Identity and Politics

University of Winchester

Director

Southern Policy Centre

John.Denham@Winchester.ac.uk

Second Author

Daniel Devine

PhD Candidate in Politics

University of Southampton

D.J.Devine@Soton.ac.uk 


\section{INTRODUCTION}

In the last few years, the role of English identity has come to the fore, spurred on by the rise of strong national identities in Scotland and Wales and the referendum on membership of the European Union. Over the last five years, this has generated considerable academic and political interest, with literature detailing what English nationhood is and its direct effects on British politics, such as the Brexit vote. ${ }^{i}$ Moreover, the development of an identity of Englishness has been linked to wider, more profound changes in the structure of British politics, with the divide between the non-cosmopolitan areas of the UK, where English identity is strongest, and cosmopolitan cities, where it is weaker.i ${ }^{\text {ii }}$ This is of particularly concern to the Labour Party due to descriptive evidence that English-identifying voters are less likely to support them, the poor performance in 2015, and further, its failure to convince English-identifying voters in the 2017 snapelection. iii

For obvious reasons, recent work has focused on the role of Englishness in the Brexit vote. In this contribution, we want to explore how Englishness 'play[s] in other ways into the future of UK domestic politics.' ${ }^{\text {iv }}$ In particular, we want to go to the heart of representative politics and ask whether English identity conditions even citizens' leftright placement of political parties - in this case, the Labour Party. This is of theoretical interest and importance, given the role of ideological placement within political science and electoral competition. ${ }^{v}$ However, of more pressing interest is its practical, political importance. If left-right placement matters, it might be that Labour's poor performance amongst English-identifying voters is precisely due to the effect on the perception of Labour's ideological position, and is indicative of other relevant policy differences. This is the hypothesis we take up here.

In the next section, we reflect on identity politics and Englishness specifically, and how this could impact perceptions of politics. We then provide empirical analysis of the question, showing initially whether 'strongly English' voters position Labour differently compared to other respondents and other parties, before investigating whether this holds up in statistical analysis. Ultimately, we argue that Englishness as an identity can indeed reach into even fundamental perceptions of the political system, in this case leftright placement. However, in line with previous research, a lack of perceived political efficacy, immigration, and age condition ideological placement as well. On the basis of this, we also provide potential routes Labour can take to address this gap between itself and English-identifying voters.

\section{IDENTITY AND ENGLISHNESS}

The idea that identity shapes perceptions of political phenomena is not new. We know well that group identity, from ethnic to occupational and especially partisanship, shape political preferences. For example, perceptions of largely objective economic conditions are conditioned by partisanship, and similarly the perception of how well democracy is working is conditioned by whether one is a supporter of the winning coalition. Some authors go as far as arguing that reasoned explanations for beliefs and behaviour are just justifications of social or partisan loyalties. ${ }^{\mathrm{vi}}$ More directly related, we know that

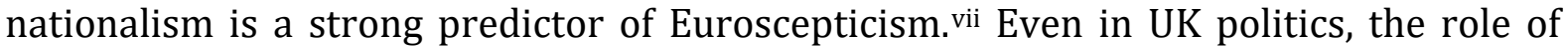
national identity has been seen as a significant factor in understanding Scottish, Welsh 
and Northern Irish politics. However, such focus has not been afforded to explicitly English identity which has been largely subsumed into a broader discussion on British politics, a position which now seems untenable given the growing evidence of the politicisation and mobilisation of English identity.

Even work that does use Englishness as an explanatory variable does not typically focus on it specifically, with the notable exception of Henderson et al. For instance, whilst studies focus on various explanations for voting leave, and find Englishness to be important, this is not developed further or given the status of a key explanatory variable. viii This is perhaps because Englishness is seen as a meeting point for a range of other factors and beliefs, such as Euroscepticism, rather than an independent driving force. This is, of course, true. Unlike demographics or even survey questions which address political attitudes directly, identity is going to consist of a bundle of attitudes that shape people's views of themselves, their community, and predispose them to certain attitudes towards political and social phenomena (i.e, act as a perceptual screen). As such, whilst it is important not to treat Englishness, or any other identity, as purely independent, what it represents should be given proper consideration.

Nonetheless and aside from these caveats, in previous work it is found that Englishness remains a statistically and substantively significant predictor of the vote for Brexit. Moreover, we also know that English-identifiers are more likely to reside in noncosmopolitan areas, and that this is an increasingly important cleavage in British - or English - politics. This justifies our decision to expand the analytical scope of Englishness from direct decisions, like voting, to whether it acts like other group identities in conditioning perceptions of other political phenomena, with a focus on the Labour Party - a party which has struggled in England in recent years, particularly amongst English identifiers. We show next why this is empirically an interesting question before developing the analysis.

\section{DESCRIPTIVE ANALYSIS}

There are two primary ways to measure English identity. The first is the 'Moreno' scale, which asks respondents to order their identity from 'British only', 'Mostly British not English', 'equally British and English', and vice versa. Alternatively, there is a measure of intensity that asks respondents to rank the 'intensity' of their identity from 1 (not at all English) to 7 (very strongly English). Following Goodwin and Heath's work on the Brexit vote, we opt for the latter. This is also due to the quality of the data, with the intensity scale being fielded in the British Election Study, and it also being the most recent data available at the time of writing. We use Wave 10, which was fielded between November and December 2016. Later waves were not used because of missing data on key variables of interest.

Turning firstly to some descriptive statistics, Figure 1 displays the distribution of English identity across the full scale. Approximately $50 \%$ of respondents rate themselves as 'very strongly' English, at the maximum of the response scale. A considerable majority, therefore, feel more English than not.

A downside of not using the Moreno scale is that it could be that the Englishness measure is simply reflecting nationalism. For sure, many people hold both intensely strong English 
and British identities. Whilst this is true to some extent, statistical tests described in the results show that Englishness captures an alternative dimension to Britishness.

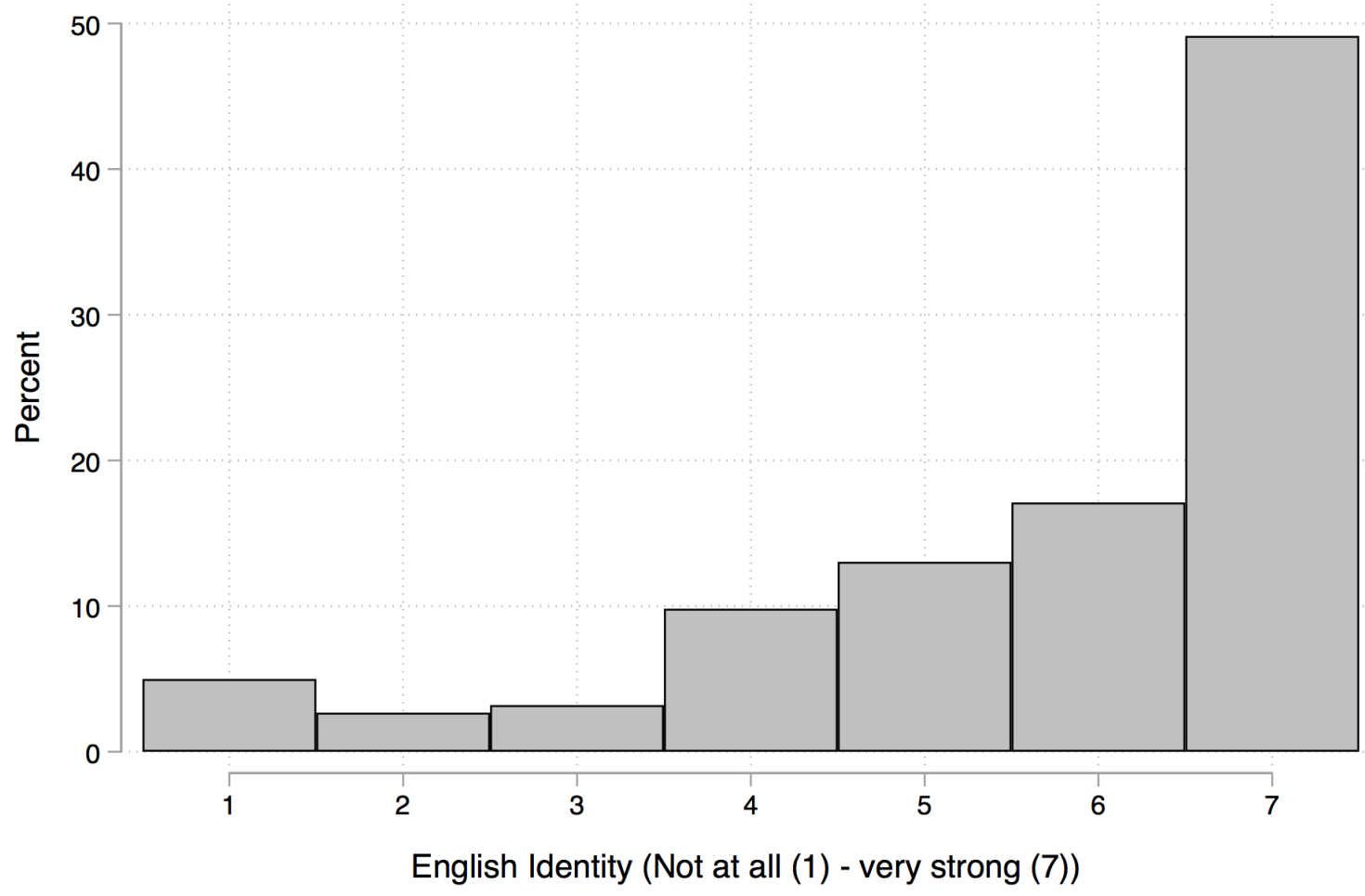

Figure 1: Distribution of English Identity Responses

Figures 2 below shows the political distinctiveness of those English-identifying voters, with the darker grey representing those who identify as strongly English. On average, they place themselves further right on the left-right continuum. Similarly, they are 50\% less likely to have recall voting for Labour in the 2015 General Election (data not shown). This highlights the importance of this question for the Labour Party: a significant group of the electorate hold an increasingly politicised identity which seems anathema to the party. The prevalence of this English identity could be problematic if it is acting as a perceptual screen for these voters; it may also, more generally, act as a proxy indicator for other latent attitudes. 


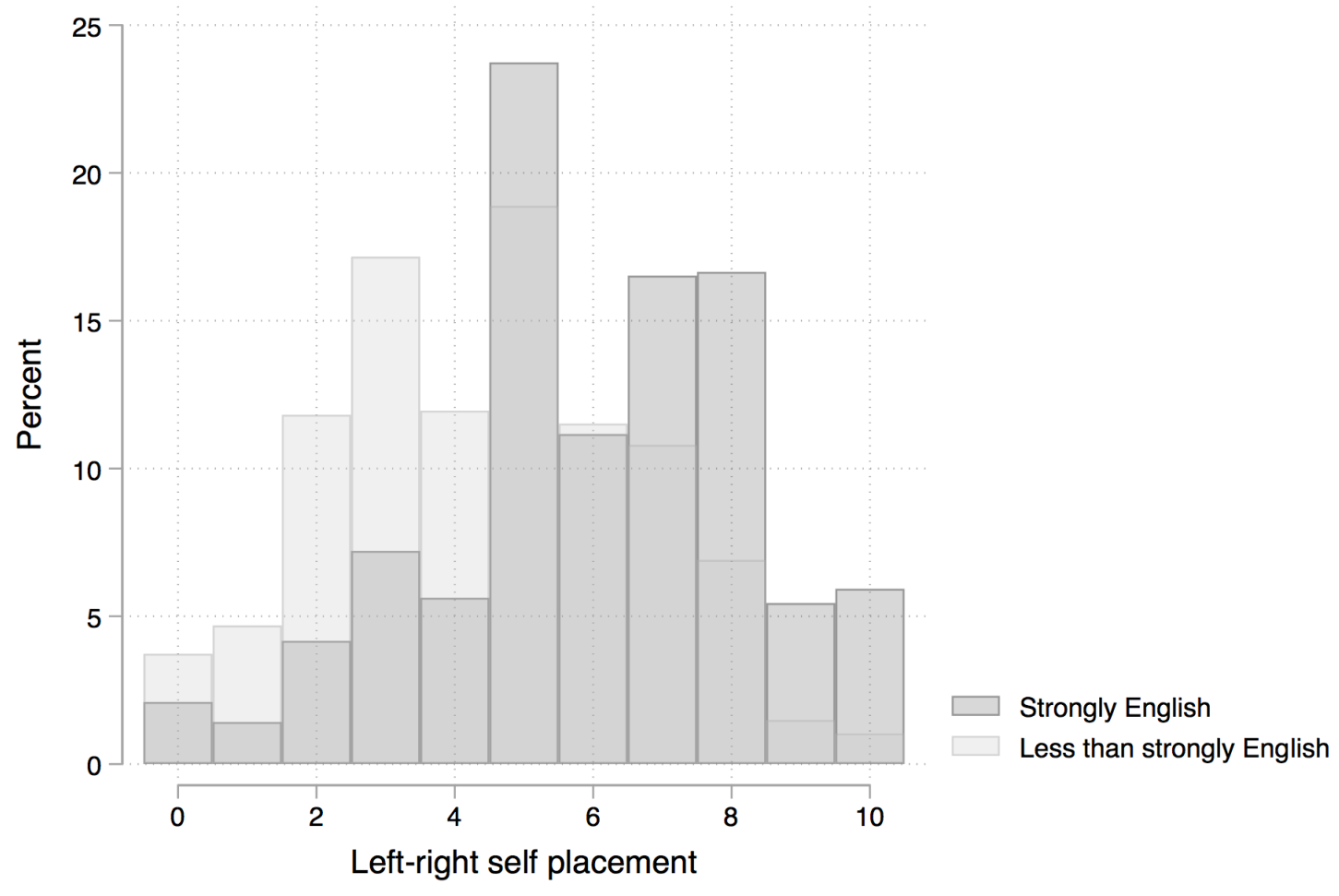

Figure 2: Left-Right Placement by English Identity

Figure 3 graphs the primary relationship under consideration in this contribution: the left-right placement of the Labour Party from strongly English identifiers. For comparison, the placement of the Conservatives is also graphed. Approximately $40 \%$ of those who are strongly English see Labour as a far-left party; as far left as possible. However, the Conservatives are rather more accurately placed with a largely centre-right distribution. This comparison becomes even starker once the positioning for nonstrongly English identifiers is considered, presented in Figure 4. The distribution of responses for the Conservatives is much the same; the real difference is for the Labour Party. It should be noted that the Liberal Democrats also see a $10 \%$ difference on the most left response (data not shown), indicating that it may be a problem for left-of-centre parties in general, of which Labour is clearly the most pertinent. 


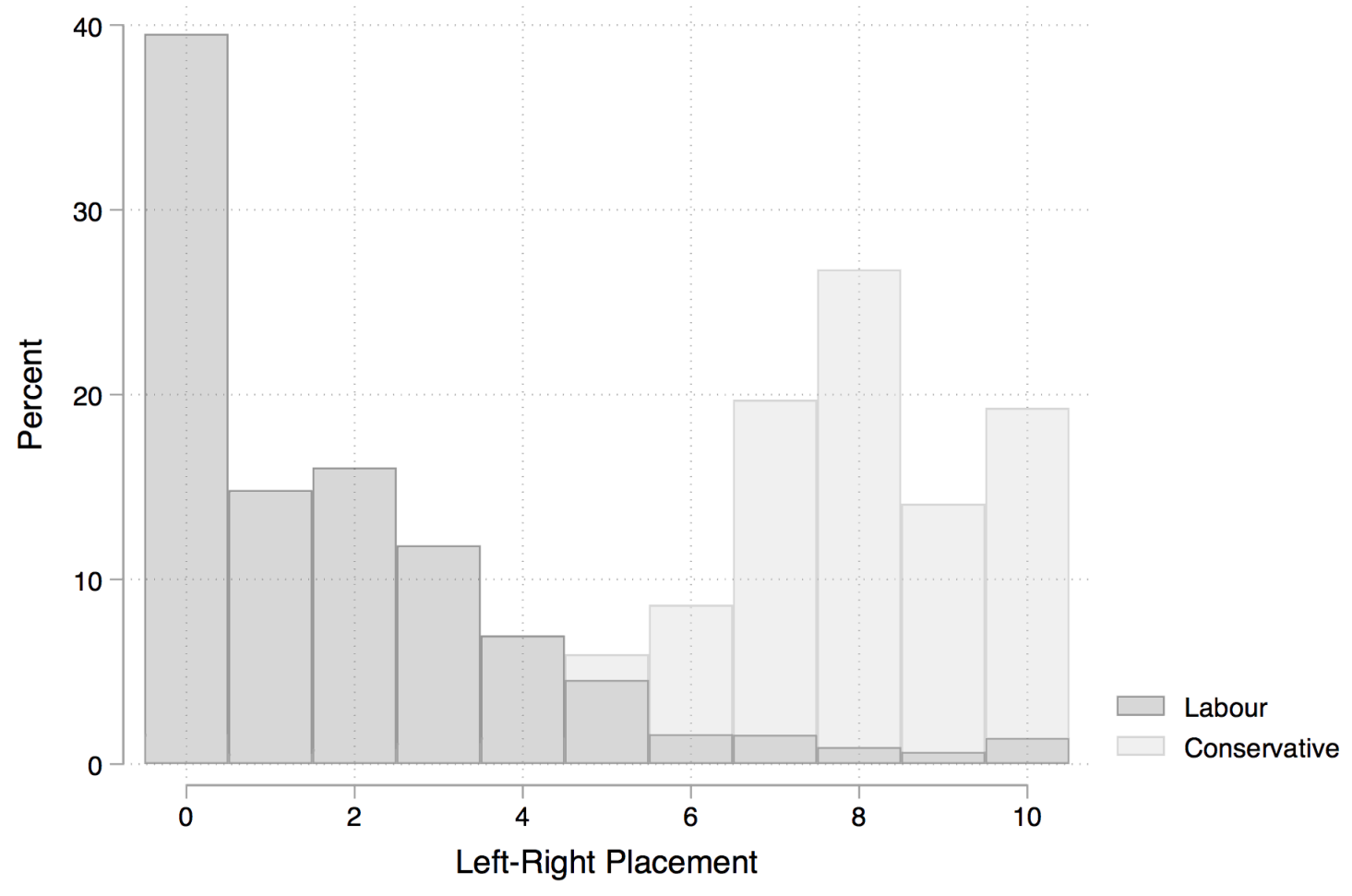

Figure 3: Left-Right Placement of the Three Main Parties by 'Strongly English' identifiers

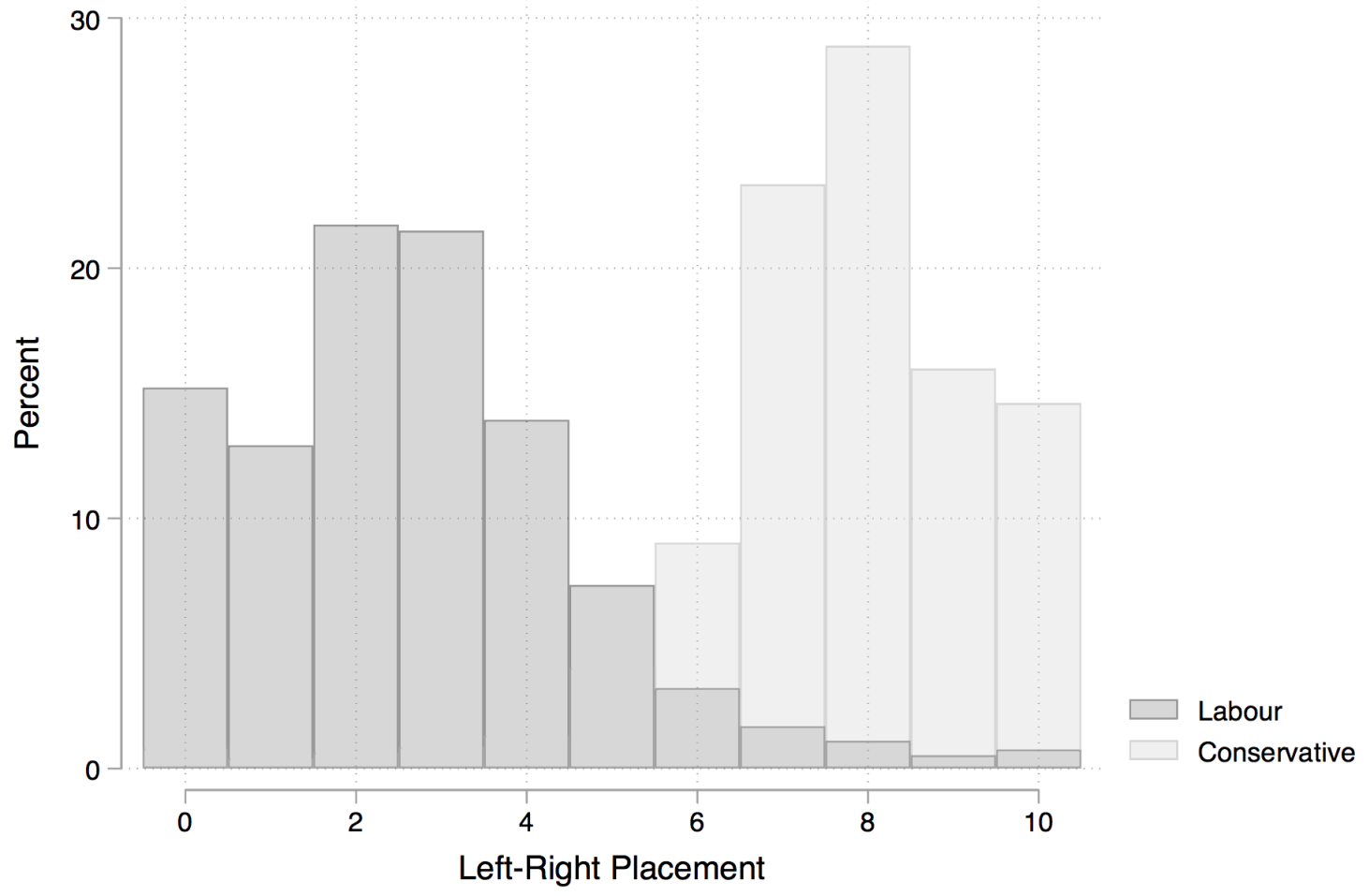

Figure 4: Left-Right Placement of the Three Main Parties by less than 'Strongly English' identifiers 
This is potentially problematic for Labour because, following spatial models of voting, voters vote for those they perceive as spatially close to them. If voters do not perceive Labour as ideologically close, they are theoretically less likely to vote for them. If English identity conditions Labour to be perceived as more left, this could offer indications to why Labour struggles so much in England, given that $50 \%$ of the population identify as such, and that this is concentrated in key Labour constituencies. It could also suggest problems in the future if English identity is increasingly linked to voting behaviour or becomes increasingly politicised and mobilised. This is doubly problematic because these voters do not differ substantially on social and economic policy, in which Labour is in tune. More generally, it shows the strength of the identity that it acts as a perceptual screen for a fundamental aspect of democratic politics.

\section{REGRESSION ANALYSIS}

It could be that this is simply reflecting the characteristics of those who identify as strongly English, since they are older, typically less formally educated, and tend to be more right-wing themselves. To explore this further, we present below three linear regression models. The dependent variable is left-right placement of the Labour Party on a scale from 0 (left) to 10 (right); the key explanatory variable is Englishness on a scale from 1 (not at all English) to 7 (strongly English).

We include a range of other variables that could be related to people's subjective leftright placement of the Labour Party, which is informed by previous studies on Englishness as well as work on the cosmopolitan/non-cosmopolitan divide. Alongside demographics such as age, education, income and gender, we include a range of political attitudes: political attention on a 0-10 scale, since this could influence the accuracy of leftright placement; to gauge the respondent's own ideological position, we include their own left-right placement and their position on a calculated liberal-authoritarian scale. We also include a range of more general political attitudes: the level of political efficacyix, since English-identifiers are also more likely to be politically disaffected; their own party identification; the position that the respondent believes Labour has on redistribution, which theoretically is key to left-right placement; and whether or not they like or dislike Corbyn as a measure of leadership judgement. Finally, we have three variables that tap into perceptions on immigration: whether it has a positive negative impact on the economy, cultural life, and how they believe it would change under a Labour government. The demographic variables are introduced in Model 2 with attitudinal variables being introduced in Model 3.

What the results show is that Englishness is a significant predictor across all three models. It is substantively weakened when controlling for other attitudes in the third model. It means that from the final model, someone who identifies as 'strongly English' is only likely to see the Labour Party as .3 more to the left on a 0-10 scale than someone who identifies as 'not at all English', holding all other variables constant. However, given that there are so many controls for logically and theoretically important variables, that it remains statistically important is interesting in itself. As we discussed above, we should not expect the impact of national identity to be independent of demographics or attitudinal variables like left-right position. There is clearly going to be a complex causal story behind the development of identity and what types of attitudes it predisposes those who hold it to. Since we know that is more prevalent in communities of those who feel 
disempowered and have experienced major economic and social change, it would be surprising to find that the economic and social reality is not reflected in, or reinforcing, this perception of national identity. In other words, the relationship between 'Englishness' and the Labour Party is captured by a range of demographic and attitudinal variables, but seems to exert a small but statistically significant effect by itself.

For interest, we also included Britishness as the main variable of interest, both alongside and without Englishness. In neither model did Britishness become significant or near, and the coefficient on Englishness did not change. This assures us that this is not just latent nationalism and that British and English identity exert different influences on left-right placement of Labour. In the case of Britishness, it does not seem to exert any influence.

\begin{tabular}{|c|c|c|c|}
\hline VARIABLES & $\begin{array}{c}\text { (1) } \\
\text { Bivariate Model } \\
\end{array}$ & $\begin{array}{c}\text { (2) } \\
\text { Demographics } \\
\end{array}$ & $\begin{array}{l}(3) \\
\text { Full } \\
\end{array}$ \\
\hline Englishness & $\begin{array}{l}-0.212^{* * *} \\
(0.0146)\end{array}$ & $\begin{array}{l}-0.130^{* * *} \\
(0.0183)\end{array}$ & $\begin{array}{c}-0.0447^{* *} \\
(0.0204)\end{array}$ \\
\hline \multicolumn{4}{|l|}{ Age } \\
\hline $18-25$ & & $\begin{array}{c}0.0385 \\
(0.305)\end{array}$ & $\begin{array}{c}0.224 \\
(0.220)\end{array}$ \\
\hline $26-35$ & & $\begin{array}{c}0.233 \\
(0.305)\end{array}$ & $\begin{array}{c}0.148 \\
(0.224)\end{array}$ \\
\hline $36-45$ & & $\begin{array}{l}-0.515^{*} \\
(0.297)\end{array}$ & $\begin{array}{l}-0.374^{*} \\
(0.213)\end{array}$ \\
\hline $46-55$ & & $\begin{array}{c}-0.923^{* * *} \\
(0.293)\end{array}$ & $\begin{array}{c}-0.718^{* * *} \\
(0.207)\end{array}$ \\
\hline $56-65$ & & $\begin{array}{l}-1.320^{* * *} \\
(0.292)\end{array}$ & $\begin{array}{c}-0.795^{* * *} \\
(0.206)\end{array}$ \\
\hline $65+$ & & $\begin{array}{l}-1.599 * * * \\
(0.295)\end{array}$ & $\begin{array}{c}-1.126^{* * *} \\
0.224\end{array}$ \\
\hline \multicolumn{4}{|l|}{ Education } \\
\hline GCSE D-G & & $\begin{array}{l}-0.0438 \\
(0.212)\end{array}$ & $\begin{array}{l}-0.0363 \\
(0.220)\end{array}$ \\
\hline GCSE A*-C & & $\begin{array}{c}-0.455^{* * *} \\
(0.147)\end{array}$ & $\begin{array}{c}-0.398^{* *} \\
(0.155)\end{array}$ \\
\hline A-Level & & $\begin{array}{l}-0.482^{* * *} \\
(0.144)\end{array}$ & $\begin{array}{c}-0.447^{* * *} \\
(0.153)\end{array}$ \\
\hline Undergraduate & & $\begin{array}{l}-0.386^{* * *} \\
(0.144)\end{array}$ & $\begin{array}{c}-0.321^{* *} \\
(0.153)\end{array}$ \\
\hline Postgraduate & & $\begin{array}{l}-0.296^{*} \\
(0.158)\end{array}$ & $\begin{array}{l}-0.304^{*} \\
(0.163)\end{array}$ \\
\hline Income & & $\begin{array}{l}-0.0581^{* * *} \\
(0.00925)\end{array}$ & $\begin{array}{l}-0.0229 * * \\
(0.00947)\end{array}$ \\
\hline Gender (Female) & & $\begin{array}{c}-0.182^{* * *} \\
(0.0617)\end{array}$ & $\begin{array}{l}-0.241^{* * *} \\
(0.0650)\end{array}$ \\
\hline Political Attention & & & $\begin{array}{l}-0.0301 \\
(0.0197)\end{array}$ \\
\hline Left-Right Self-Placement & & & $\begin{array}{c}0.0626^{* * *} \\
(0.0203)\end{array}$ \\
\hline \multirow{2}{*}{$\begin{array}{l}\text { Authoritarian-Liberalism } \\
\text { Scale }\end{array}$} & & & $0.0610^{* * *}$ \\
\hline & & & $(0.0196)$ \\
\hline Political Efficacy & & & $\begin{array}{l}0.259^{* * *} \\
(0.0664)\end{array}$ \\
\hline Party ID & & & $\begin{array}{c}0.0394^{* * *} \\
(0.0104)\end{array}$ \\
\hline Labour Redistribution & & & $0.108^{* * *}$ \\
\hline
\end{tabular}



under Labour

\begin{tabular}{|c|c|c|c|}
\hline \multicolumn{3}{|l|}{ A Lot Lower } & $\begin{array}{l}-0.750 * \\
(0.408)\end{array}$ \\
\hline \multicolumn{3}{|l|}{ A Little Lower } & $\begin{array}{c}0.453^{*} \\
(0.262)\end{array}$ \\
\hline \multicolumn{3}{|l|}{ A Little Higher } & $\begin{array}{c}-0.285^{* * *} \\
(0.0812)\end{array}$ \\
\hline \multicolumn{3}{|l|}{ A Lot Higher } & $\begin{array}{c}-1.113^{* * *} \\
(0.101)\end{array}$ \\
\hline Constant & $\begin{array}{l}3.557^{* * *} \\
(0.0851)\end{array}$ & $\begin{array}{c}4.860^{* * *} \\
(0.332)\end{array}$ & $\begin{array}{c}1.573^{* * *} \\
(0.485)\end{array}$ \\
\hline Observations & 11,401 & 7,580 & 5,390 \\
\hline R-squared & 0.028 & 0.101 & 0.263 \\
\hline
\end{tabular}

Table 1: Regression Analysis Predicting Left-Right Placement of Labour

In terms of demographics, education and income exert statistically significant effects, as does education, but only for those with GCSEs and A-Levels, and it tails off at degree-level. By far the most substantively important variables are age (limited to those over 65), the perception that immigration will increase 'a lot' under Labour, and whether or not the respondent likes or dislikes Corbyn. Interestingly given previous research, the perceived political efficacy of the respondent also influences placement of Labour: those who see themselves as less able to understand or influence the political system see Labour further to the left. Moreover, the issue of immigration seems to be cultural rather than economic given the significance of their respective variables - to the extent that these can be separated. The substantive effect for the perceived cultural impact is nonetheless quite marginal, with those who see it as a very bad cultural impact likely to see Labour just 0.4 more to the left on the 0-10 scale than those that see it as very positive.

Overall, this exploratory analysis presents findings similar to other recent work on Englishness and in particular its role in Brexit. We find, specifically, that English identity can drive even the left-right placement of the Labour Party, even controlling for a range of relevant factors, though the substantive effect is small. This supports previous research that has shown it being related to more direct political acts like voting. Like other analyses, we find that age and immigration - in this case, its perceived increase under Labour rather than any actual economic or cultural impact - matters. We also find evidence of the 'left-behind' argument, with those who are less efficacious putting Labour further left. 
This finding, along with other recent work on Englishness, indicates that it is an identity which exerts some impact on fundamental political views, which could prove troubling for Labour. It must perform better in England; yet, it struggles to appeal to those outside of core metropolitan cities. As we have seen, large numbers of people identify as English, and feel strongly English. If Labour wishes to gain support in non-cosmopolitan areas it may have to engage with the issues that appear to be driving these English identifiers if it becomes a mobilised identity. At the same time, despite the demise of UKIP, scope clearly exists for other political forces to mobilise this group of voters.

More positively, these voters are at least as open as other voters to Labour's message on redistribution and public spending. Whilst they are on average more authoritarian, this does not spill over into markedly different views social policy on education or the NHS, for example.x They were however much more likely to vote for Brexit, are much stricter on immigration, and are more sceptical of politicians and the political system. As we show above, these factors also influence how they perceive the Labour Party - a problem that is exclusively for Labour.

It is fairly straightforward to outline the challenge facing Labour, but there is considerable scope for debate about the most effective response. Ultimately, to increase chances of electoral success, the gap between these English-identifying voters and their perception of Labour should be closed. The placement of Labour as a far-left party does not seem to be strongly rooted in a real gap between the party's social policies and those of the voters' preferences. Rather, the gap seems to reflect perceptions of immigration policy, perceptions of the party leader (perhaps in these surveys as a surrogate for the party itself), and the disempowerment felt by voters; and, in terms of demographics, age.

To engage these voters with Labour's social and economic policies, where the two are largely in tune, acknowledging the importance and relevance of English identity may be a starting point. Instead of shying away from these issues, the party can acknowledge that English identity is a valid one, particularly given its breadth and depth. ${ }^{x i}$ There is no reason why Labour cannot construct a progressive message by speaking directly to the issues of Englishness without compromising its commitment to social justice or legitimising those aspects which are in conflict with Labour's social message.

Yet, it is immigration that Labour has found most challenging, a challenge which is not unique to but is particularly acute for Labour. Clearly there is room for debate about Labour's immigration policy. Past attempts to change the discourse about migration's negative impact, prevalent in the media, and to convince voters that they are mistaken about the impact of immigration have not had notable success. Nor have reassurances about Labour's commitment to managing migration.

In interpreting the options open to Labour, it is worth focusing on two perspectives dominant in current work: that of the cultural backlash hypothesis, and that of the focus on the social and economic inequality that, for some, underlies this backlash. ${ }^{x i i}$ In the former, the focus is on the 'concern about immigration and expression of national identity', whilst the latter focuses on divides in wealth and the strain on public services in the wake of austerity. Whilst disentangling the causal ordering of these is not possible from this analysis, we argue that their concerns about immigration are rooted in their 
sense of powerlessness, exacerbated by economic change, as well as fears about cultural change. It should be noted though that the latter's impact on left-right placement is marginal.

To address this, perhaps more important than migration policy itself, Labour will need to acknowledge the disempowerment of these voters in its language and in the economic priority it accords the needs of their communities relative to other parts of the country.xiii Moreover, there is widespread support for migration that benefits both the settled population and migrants, and so Labour should make it clear that policy will benefit those currently resident in the communities. Beyond this, the delivery of policy will need to enable voters to become actors in changing their own communities, not just passive recipients of public policy. Encouraging trades union membership, campaigns for an increased living wage, enhanced rights to shape local policy, and party membership and engagement may all play a role in increasing political efficacy and addressing social and economic inequality, alongside clear priorities for public spending and infrastructure investment.

More directly, during and after the 2017 election, Labour leader Jeremy Corbyn as well as John McDonnell suggested that free movement would end when the UK left the EU, that migrant numbers would probably fall, and, while defending the need for migration, he sought to allay fears about migrants undermining wages and working conditions, thus focusing on the impact of migration on social justice. Whether this compromise will sit with other sectors of Labour's support remains to be seen, particularly as Labour's position on Brexit comes under closer scrutiny. A more practical response along these lines may be a transparent process of population projections at local authority, regional and national level and appropriate protection of public services, shifting the narrative towards the harm done by ongoing public under-investment.

It is, finally, important to recognise that, as Curtice and Heath argue, there is nothing inevitable about the association of Englishness with an exclusive or ethnic conception of identity. xiv While there will always be those whose allegiance to a particular identity and whose objection to immigration is founded in racism, and who Labour could not and should not reach, it is a bigger mistake to avoid the conversation altogether, generating the belief that Labour is not responsive to large parts of the electorate.

\section{CONCLUSION}

Englishness is a developing phenomenon that will not be ended by Brexit or the demise of UKIP. As we have shown, alongside driving the Brexit vote specifically, it also acts as a perceptual screen for other aspects of British politics. It offers a particular challenge to the Labour Party, our focus here, who have struggled to engage those voters outside of its metropolitan core - yet, who must speak to those voters to be able to win in England. We have given one example of this, namely, that it colours even how voters perceive Labour's ideological position.

This adds more evidence to the growing body of work that documents a complex nexus between Englishness, immigration, 'left-behindedness', and a perceived lack of political efficacy. It has been proposed here that addressing the issue of Englishness and acknowledging it as a source of identity can be well combined with Labour's economic 
and social message to reach these citizens. After all, Labour increased its vote share amongst the 'new working class' in the 2017 General Election, showing that its message is not lost. ${ }^{\mathrm{xv}}$ Moreover, there is a clear relationship between relative economic decline and a poor electoral performance for Labour. xvi Combining Labour's popular economic message and reaching out to these 'lost voters' with the language of Englishness may alleviate or reverse this trend. It is also quite possible, of course, that Labour can manage without this: if, for example, public attention is more squarely focused on 'Labour issues' such as the NHS. Yet this is not a given, and the argument here is that turning a focus to this may help close the 'perception gap' of English-identifying voters, in turn benefiting the party electorally.

Given the complexity of these issues, it is important to note that many of these relationships will be endogenous. For example, it is possible that perceiving Labour as left-wing influences the perception that immigration would increase under their government. The theoretical uncertainty shows the early development of this attitudinal dimension, where we know little about the potential causal pathways through which Englishness and its associated attitudes operate. Ideally, more qualitative research could focus on exploring the complex relationships which underlie this cluster of attitudes. Here, variable selection has been informed by previous work on Englishness and the (non-)cosmopolitan divide. In addition, the analysis presented is a cross-sectional one, and comes with these caveats. The findings will hopefully encourage a broader range of research into the consequences of British and English identity on British political life beyond the act of voting.

Going forward, understanding the complex pathways through which Englishness works is important. In addition, this contribution, like other analyses, leaves out the issue of geography. We know from the work of Jennings and Stoker that geographical variation is important, and this is likely to have an effect here. Exploring the geographical variation of types of Englishness would be an interesting next step. In light of this, it is also worth considering the possibility that there is quite a lot of variation in what people see as Englishness. We do not study this here, but work which sought to separate out the different strands of Englishness - if there are any - would prove valuable. It might be that Labour suffer with certain types of English identity but not others.

i M. Kenny, The Politics of English Nationhood, Oxford, Oxford University Press, 2014; A. Henderson, C. Jeffery, D. Wincott, R. Wyn Jones, 'How Brexit was made in England', British Journal of Politics and International Relations (forthcoming), 2017; C. Jeffery, A. Henderson, R. Scully, R. Wyn Jones, 'England's Dissatisfactions and the Conservative Dilemma', Political Studies Review, vol.14, no.3, 2016.

ii W. Jennings and G. Stoker, 'The Bifurcation of Politics: Two Englands', The Political Quarterly, vol. 87, no. 3, 2016, pp. 372-82; W. Jennings and G. Stoker, 'Tilting Towards the Cosmopolitan Axis? Political Change in England and the 2017 General Election', The Political Quarterly, vol. 88, no. 3, 2017, pp. 359-369

iii J. Denham and D. Devine, 'English Identity and the Governance of England', British Academy, 2017

iv Henderson et al, 'How Brexit was made in England'.

v A. Downs, An Economic Theory of Democracy, New York, Harper, 1957 
vi C. H Achen, L. M Bartels, Democracy for Realists: Why Elections Do Not Produce Responsive Government, Princeton, Princeton University Press, 2016.

vii G. Marks and L. Hooghe, 'Calculation, Community and Cues: Public Opinion on European Integration', European Union Politics, vol.6, no.4, pp.419-443.

viii M Goodwin and 0. Heath, Brexit vote explained: Poverty, low skills and lack of opportunities, Joseph Rowntree Foundation, Available at:

https://www.jrf.org.uk/report/brexit-vote-explained-poverty-low-skills-and-lackopportunities; M Goodwin and C Milazzo, Taking back control? Investigating the role of immigration in the 2016 vote for Brexit, British Journal of Politics \& International Relations, vol.19, no.3, pp.450-464.

ix This is calculated as the mean of the five 'efficacy' variables, which are responses on a 5-point scale (strongly disagree to strongly agree) to the items: 'it takes too much time and effort to be active in politics'; 'I have a pretty good understanding of the important political issues facing our country'; 'It is difficult to understand what happens in government and politics'; 'politicians don't care what people like me think'; and 'it doesn't matter which political party is in power'.

x Denham and Devine, 'English Identity and the Governance of England'.

xi Kenny, The Politics of English Nationhood, pp.240-241.

xii Jennings and Stoker, 'Tilting Towards the Cosmopolitan Axis?', p367; R. Ford and M. Goodwin, Revolt on the Right, London, Routledge, 2014.

xiii See, for example: P. Waugh, Jeremy Corbyn 'Can Become PM' If He Wins A Few Hundred Votes In Small Towns Battleground - New Research: Exclusive study by new 'Centre for Towns' think tank, Huffington Post, 2017, available at: < http://www.huffingtonpost.co.uk/entry/jeremy-corbyn-can-become-pm-if-he-wins734-votes-in-45-small-towns-centre-for-towns-think-

tank uk 59f23593e4b07fdc5fbcebe8 >

xiv J. Curtice and 0. Heath, 'England Awakes? Trends in National Identity in England', pp.41-63 in: F. Bechhofer and D. McCrone (eds.), National Identity, Nationalism and Constitutional Change, London, Palgrave Macmillan, 2009.

$\mathrm{xv}$ Jennings and Stoker, 'Tilting Towards the Cosmopolitan Axis?'

xvi W. Jennings, W. Brett, A. Bua, and Rachel Laurence. Cities and Towns: The 2017

General Election and the Social Divisions of Place, New Economics Foundation, 2017. 